\title{
Jumain modia wantana Ekronomitas \\ Analisis Penentuan Harga Pokok Produksi Dengan Metode Full Costing Sebagai Dasar Penetapan Harga Jual Pada Usaha Tempe Makmur Yaya Tebeng Kota Bengkulu
}

\author{
Niken Faradela ${ }^{1}$, Ida Anggriani ${ }^{2}$, Rinto Noviantoro ${ }^{3}$ \\ ${ }^{1}$ Fakultas Ekonomi Universitas Dehasen Bengkulu, Faradelaniken@gmail.com \\ ${ }^{2}$ Fakultas Ekonomi Universitas Dehasen Bengkulu, ida.anggriani26@gmail.com \\ 3Fakultas Ekonomi Universitas Dehasen Bengkulu, rintonoviantoro@yahoo.co.id
}

\begin{abstract}
ABSTRAK
Permasalahan yang terjadi pada Usaha Tempe Makmur Yaya Tebeng Kota Bengkulu adalah masih keliru dalam perhitungan karena masih ada biaya overhead pabrik yang belum di perhitungkan dalam penentuan harga pokok produksi. Tujuan dari penelitian ini adalah mengetahui perhitungan harga pokok produksi dalam penentuan harga jual pada Usaha Tempe Makmur Yaya Tebeng, Bengkulu. Metode yang digunakan dalam penelitian ini adalah metode deskriftif kuantitatif menggunakan alat atau metode full costing dan penentuan harga jual menggunakan metode full plus pricing.Berdasarkan perhitungan harga pokok produksi yang dilakukan usaha tempe makmur Yaya harga pokok produksi perbuah pada tahun 2019 adalah sebesar Rp.3.531, pada tahun 2020 sebesar Rp.3.490 dan pada tahun 2021 adalah sebesar Rp.3.492. sehingga Laba yang diperoleh tahun 2019 sebesar Rp.1.469 perbuah, tahun 2020 sebesar Rp.1.510 perbuah dan pada tahun 2021 sebesar Rp.1.508 perbuah. Sedangkan Berdasarkan perhitungan harga pokok produksi menggunakan metode full costing harga pokok produksi tempe perbuah tahun 2019 adalah sebesar Rp. 3.556, tahun 2020 sebesar Rp.3.559 dan pada tahun 2021 adalah sebesar Rp. 3.560. sehingga laba yang diperoleh pada tahun 2019 sebesar Rp.1.444 perbuah, tahun 2020 sebesar Rp.1.441 perbuah dan pada tahun 2021 sebesar Rp.1.440 perbuah. Dengan penetapan harga jual sebesar $25 \%$ dari harga pokok produksi. Terdapat selisih perhitungan harga pokok produksi antara perhitungan pabrik dengan perhitungan dengan metode full costing karena pada perhitungan pabrik tidak memasukan biaya overhead pabrik.
\end{abstract}

Kata Kunci : Harga Pokok Produksi, Penentuan harga jual

\section{ABSTRACT}

The problems that occured at Tempe Makmur Yaya business were still mistakenly in calculation because there are still overhead costs that have not been calculated in determining the cost of production. The purpose of this study is to find out the calculation of the cost of production in determining the selling price at the Tempe Makmur Yaya Tebeng business, Bengkulu. The method used in this study is a quantitative descriptive method by using the full costing method and determining the selling price using the full plus pricing method. Based on the calculation of the cost of production carried out by the Tempe Makmur Yaya business, the cost of production per piece in 2019 was 3,531 IDR, 3,490 IDR in 2020 and 3,492 IDR in 2021. Thus, the profit earned in 2019 was 1,469 IDR per pieces, 1,510 IDR per piece in 2020 and 1,508 IDR per piece in 2021. Meanwhile, based on the calculation of the cost of production using the full costing method, the cost of production of tempe per piece in 2019 is 3,556 IDR, 3,559 IDR in 2020 and 3,560 IDR in 2021. So that, the profit earned in 2019 was 1,444 IDR per piece, 1,441 IDR per piece in 2020 and 1,440 IDR per piece in 2021. With the determination of the selling price of $25 \%$ of the cost of production, there is a difference in the calculation of the cost of production between the factory calculations and the calculations using the full costing method because the factory calculations do not include overhead costs.

Keywords : Cost of Production, Determination of the selling price

\section{A. PENDAHULUAN}

Setiap perusahaan pasti memiliki tujuan yang ingin dicapai, antara lain: memperoleh keuntungan yang sebesar-besarnya, mampu bersaing di pasar, dan 
mampu memberikan manfaat bagi masyarakat. Agar suatu perusahaan dapat memperoleh laba, perusahaan harus dapat melakukan kegiatan penjualan yang paling menguntungkan, salah satu indikatornya adalah laba kotor. Laba kotor dipengaruhi oleh harga jual, biaya produksi dan volume penjualan. Harga jual produk ditentukan oleh harga pokok produksi, jika perhitungan harga pokok produksi tidak tepat maka akan mempengaruhi penentuan harga jual produk yang tidak tepat. Misalnya, menghitung biaya produksi yang tinggi akan menyebabkan penentuan harga yang tinggi, akibatnya suatu produk tidak mampu bersaing di pasar. Begitu juga sebaliknya, jika perhitungan harga pokok produksi rendah maka akan menghasilkan harga produksi yang rendah dan akibatnya perusahaan tidak mencapai laba yang maksimal walaupun harga jual dapat bersaing di pasar.

Penetapan harga jual produk memerlukan pertimbangan yang komprehensif dari berbagai aspek, mulai dari biaya produksi, biaya operasional, target laba yang diharapkan perusahaan, daya beli masyarakat, harga jual pesaing, kondisi ekonomi, dan sebagainya. Penetapan harga jual produk perusahaan harus menjadi kebijakan yang harus diperhatikan secara matang dan terpadu. Walaupun perusahaan mempertimbangkan banyak aspek dalam menentukan harga suatu produk, namun faktor biaya sering dijadikan sebagai titik tolak untuk menentukan harga suatu produk. Harga jual produk dan kebijakan biaya akan selalu berubah sesuai dengan perubahan biaya produk dan kondisi pasar. Biaya yang dikeluarkan oleh perusahaan dalam memproduksi berbagai produk dalam jangka waktu tertentu akan dijadikan dasar penentuan harga jual produk tersebut. Jumlah keuntungan yang diinginkan perusahaan harus selalu lebih tinggi dari total biaya produksi produk. Yang diperhitungkan adalah margin keuntungan per unit produk yang dihasilkan perusahaan. Penentuan margin keuntungan di atas biaya-biaya yang dikeluarkan oleh perusahaan perlu memperhatikan keahlian khusus dari aspek-aspek yang telah disebutkan di atas. Dengan memahami harga pokok produksi, perusahaan akan dapat menentukan harga jual produknya untuk menghasilkan keuntungan. Bahkan dalam menentukan biaya produksi, perusahaan harus menentukan metode yang tepat agar nantinya dapat menghasilkan keuntungan sesuai harapan perusahaan dan bersaing dengan perusahaan lain.

Harga pokok produksi itu sendiri terdiri dari beberapa unsur, yaitu: biaya bahan baku, biaya tenaga kerja langsung dan biaya pabrik tidak langsung. Biaya bahan baku termasuk biaya yang berhubungan langsung dengan pembuatan produk. Biaya tenaga kerja langsung adalah biaya yang dibayarkan kepada personel yang terlibat langsung dalam proses produksi. Biaya pabrik tidak langsung meliputi biaya yang tidak termasuk dalam biaya bahan baku dan biaya tenaga kerja langsung.

Namun, di tengah kondisi perekonomian saat ini ketika harga-harga tengah naik tentu akan sangat sulit bagi para pelaku usaha kecil menengah (UKM) untuk menetapkan harga jual yang murah atas produk yang diproduksinya dengan kualitas yang masih tetap sama, hal ini dikarenakan biaya untuk memproduksi barang untuk produk tersebut tentu juga akan naik karena pengaruh kenaikan harga-harga yang terjadi, dalam hal ini perusahaan dituntut untuk bisa mengambil keputusan yang tepat akan permasalahan ini agar perusahaan tidak mengalami kerugian.

Tingkat pendidikan, pelatih usaha dan pengalaman manajerial sebelumnya juga dapat mempengaruhi informasi akuntansi yang tercermin dalam catatan-catatan akuntansi. Kurangnya pengetahuan atau kurangnya pelatihan pengelolaan usaha dapat mengakibatkan pelaku usaha sulit memajukan usahanya dikarenakan tidak 
dapat mengetahui informasi keuangan secara tepat sehingga dalam pengambilan keputusan menjadi tidak efektif dan terkendali.

Suatu Usaha Kecil Menengah (UKM) yang mengalami perkembangan agar dapat mencapai suatu tujuan organisasi yaitu untuk meningkatkan penjualan pada produk. Salah satunya adalah Usaha Kecil Menengah (UKM) yang sedang berkembang yaitu usaha Tempe Makmur Yaya yang terletak di kelurahan Panorama Kecamatan Singaran Pati, Kota Bengkulu.

Dalam menentukan perhitungan harga pokok produksi pada Usaha Kecil Menengah Tempe makmur Yaya hanya berfokus pada bahan baku, sedangkan dalam perhitungan harga pokok produksi biaya tenaga kerja dan biaya overhead pabrik tidak kalah penting untuk menentukan harga jual yang tepat. Yang sering temui dilapangan adalah adanya penggabungan biaya overhead untuk usaha dan pemakaian pribadi, hal ini menyebabkan meningkatnya biaya produksi. Keadaan seperti ini juga yang seringkali membuat usaha kecil menengah (UKM) seperti Tempe Makmur Yaya Tebeng sulit untuk mengembangkan usahanya ke ranah yang lebih luas lagi.

Mengingat pentingnya perhitungan harga pokok produksi bagi kemajuan perusahaan, oleh karena itu peneliti tertarik untuk melakukan penelitian dengan judul "Analisis Penentuan Harga Pokok Produksi Dengan Metode Full Costing Sebagai Dasar Penetapan Harga Jual Pada Usaha Tempe Makmur Yaya Tebeng Kota Bengkulu"

Agar penelitian ini tidak menyimpang dari permasalahan dan dapat mencapai tujuan yang diinginkan, penulis membatasi pada analisis harga pokok produksi dalam penentuan harga jual tempe kemasan plastik harga Rp. 5000 dengan margin keuntungan sebesar 25\% pada usaha Tempe Makmur Yaya dengan pendekatan metode full costing (Slamet dan Sumarli, 2015:18) dengan data-data keuangan yang diambil dari periode Agustus 2019 - Agustus 2021." Tujuan dari penelitian ini adalah mengetahui perhitungan harga pokok produksi dalam penentuan harga jual pada Usaha Tempe Makmur Yaya Tebeng Kota Bengkulu.

\section{B. KAJIAN TEORI \\ Biaya Produksi}

Menurut Mulyadi (2014:16) "Biaya produksi merupakan biaya-biaya yang dikeluarkan dalam pengolahan bahan baku menjadi produk". Menurut Bustami dan Nurlela (2013:12) "Biaya produksi adalah biaya yang digunakan dalam proses produksi yang terdiri dari bahan baku langsung, tenaga kerja langsung dan biaya overhead pabrik. Biaya produksi ini juga disebut dengan biaya produk, yaitu biayabiaya yang dapat dihubungkan dengan suatu produk, dimana biaya ini merupakan bagian dari persediaan".

\section{Harga Pokok produksi}

Firmansyah (2015:57) berpendapat bahwa harga pokok produksi adalah penjumlahan seluruh pengorbanan sumber ekonomi yang digunakan dalam pengolahan bahan baku menjadi produk jadi. Pada dasarnya tujuan penentuan harga pokok produksi adalah menentukan secara tepat jumlah biaya per unit pada produk jadi, sehingga dapat diketahui laba atau rugi suatu perusahaan per periode.

\section{Metode Full Costing}

Menurut Slamet dan Sumarli (2015:18.), mengatakan bahwa: Full costing merupakan metode penentuan harga pokok produksi yang memperhitungkan semua 
unsur biaya produksi, yang terdiri dari biaya bahan baku, biaya tenaga kerja langsung, dan biaya overhead pabrik, baik variable maupun tetap.

Dari pengertian di atas dapat ditarik kesimpulan bahwa unsur harga pokok produk menurut metode ini meliputi:

\begin{tabular}{|ll|}
\hline Biaya bahan baku & Rp. Xxx \\
Biaya tenaga kerja langsung & \multicolumn{1}{|c|}{ Rp. Xxx } \\
Biaya overhead pabrik & Rp. $x x x+$ \\
Harga pokok produksi & Rp. $x x x$ \\
\hline
\end{tabular}

Penentuan harga pokok produksi berdasarkan full costing pada umumnya ditujukan untuk kepentingan penyusunan laporan keuangan untuk pihak eksternal. Laporan laba rugi yang disusun dengan metode ini menitik beratkan pada penyajian unsur-unsur biaya menurut hubungan biaya dengan fungsi pokok yang ada di perusahaan yaitu fungsi produksi, fungsi pemasaran, serta fungsi administrasi dan umum. Dengan demikian laporan laba rugi menurut full costing akan tampak sebagai berikut:

\begin{tabular}{|c|c|}
\hline $\begin{array}{l}\text { Penjualan } \\
\text { Harga pokok penjualan }\end{array}$ & $\begin{array}{l}\text { Rp. Xxx } \\
(\text { Rp. } x x x) \\
\end{array}$ \\
\hline $\begin{array}{l}\text { Laba kotor atas penjualan } \\
\text { Lercial. }\end{array}$ & Rp. Xxx \\
\hline $\begin{array}{c}\text { Biaya komersial: } \\
\text { Pemasaran }\end{array}$ & $B n X x x$ \\
\hline Administrasi dan umum & $\begin{array}{l}\text { Rp.xxx } \\
\text { (Rp.xxx) }\end{array}$ \\
\hline Laba bersih & Rp. Xxx \\
\hline
\end{tabular}

Menurut Mulyadi (2014:17) : Pengertian metode full costing adalah metode penentuan harga pokok produksi kedalam harga pokok produksi, yang terdiri dari biaya bahan baku, biaya tenaga kerja langsung, dan biaya overhead pabrik, baik yang berperilaku variabel maupun tetap, dengan demikian harga pokok produksi menurut full costing terdiri dari unsur biaya produksi. Harga pokok produksi menurut metode full costing terdiri dari unsur-unsur biaya produksi sebagai berikut:

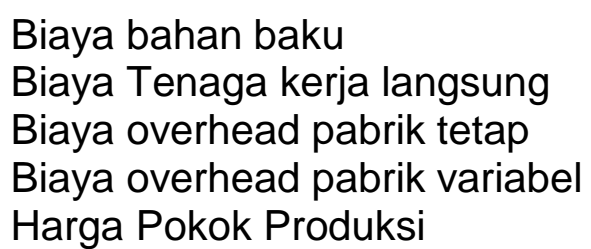
Biaya bahan baku
Biaya Tenaga kerja langsung
Biaya overhead pabrik tetap Harga Pokok Produksi

\author{
$\operatorname{Rp} x x x$ \\ $\operatorname{Rp} x x x$ \\ $\operatorname{Rp} x x x$
}

$\underline{\operatorname{Rp} x x x}$
$\operatorname{Rp} x x x$

Dari pengertian diatas dapat disimpulkan Metode full costing adalah suatu metode dalam penentuan harga pokok suatu produk dengan memperhitungkan semua biaya produksi, seperti biaya bahan baku langsung, tenaga kerja langsung, dan biaya overhead pabrik dan biaya overhead pabrik tetap.

\section{Penetapan Harga Jual}

Menurut Mulyadi (2015:78) pada prinsipnya harga jual harus dapat menutupi biaya penuh ditambah dengan laba yang wajar. Harga jual sama dengan biaya produksi ditambah mark-up. 
Ada beberapa metode penentuan harga jual tetapi yang sering dipakai adalah lima metode sebagai berikut (Slamet dan Sumarli, 2015:49.)

a. Gross Margin Pricing

Metode ini tepat digunakan oleh perusahaan perdagangan jenis perusahaan ini tidak membuat sendiri produk yang dijual sehingga tidak banyak aktiva tetap yang digunakan. Caranya dengan menentukan persentase tertentu diatas harga produk yang dibeli, persentase ini disebut "Mark On Persentage" atau Mark up.

Adapun cara menghitung Gross Margin Pricing sebagai berikut :

\section{Cost Product + (\% Mark Up x Dasar penentuan Mark Up)}

b. Direct Cost Pricing

Metode ini umumnya diterapkan pada produk yang diproduksi tetapi melebihi daya serap pasar (produk dari kapasitas yang menganggur) yang kemudian produk ini dipasarkan pada pasar yang berbeda, dengan syarat tidak merusak pasaran produk dipasaran bebas.

Adapun cara menghitung Direct Cost Pricing sebagai berikut :

\section{Persentase Mark Up = (Laba yang diharapkan + Biaya yang tidak dipengaruhi langsung oleh volume produksi / Biaya yang dipengaruhi langsung oleh biaya produksi)}

\section{c. Full Cost Pricing}

Pada metode ini semua jenis biaya dipakai sebagai dasar untuk menentukan harga jual. Jadi semua biaya untuk membuat produk tersebut dihitung ditambah persentase laba yang diinginkan.

Adapun cara menghitung Full Cost Pricing sebagai berikut :

\section{(Biaya produksi total + Margin (persentase laba) yang diinginkan}

\section{d. Time and Material Pricing}

Dalam metode ini, tarif ditentukan dari upah langsung dan tarif lain dari bahan baku masing-masing, tarif ini dijadikan satu ditambah jumlah tertentu dari biaya tak langsung serta laba yang diinginkan. Time dalam metode ini ditunjukkan oleh tarif perjam atau perwaktu dari tenaga kerja, di mana tarif tenaga kerja ini merupakan jumlah dari: Upah langsung dan premi pada karyawan, Bagian laba yang layak dan berhubungan dengan upah tenaga kerja

\section{Kerangka Analisis}

Dari kerangka analisis dibawah ini menjelaskan bahwa peneliti bermaksud untuk melakukan perhitungan biaya produksi dengan metode Full Costing untuk mengetahui harga jual. 


\title{
GAMBAR KERANGKA ANALISIS
}

\author{
Harga Pokok \\ Produksi \\ 1. Biaya bahan baku \\ 2. Biaya tenaga kerja \\ 3. Biaya overhead
}

Dari kerangka analisis di atas bisa kita lihat bahwa perhitungan harga pokok produksi memiliki tiga unsur yang harus ada yaitu : biaya bahan baku, biaya tenaga kerja, dan biaya overhead pabrik, yang selanjutnya ketiga unsur tersebut akan dihitung menggunakan metode full costing untuk penetapan harga jual. (Slamet dan Sumarli, 2015:18,49).

\section{METODE PENELITIAN}

Penelitian ini merupakan penelitian deskriptif kuantitatif, menurut Sugiyono (2013:206) deskriftif kuantitatif adalah penelitian yang digunakan dengan cara mendeskripsikan atau menggambarkan data yang telah terkumpul sebagaimana adanya tanpa bermaksud membuat kesimpulan yang berlaku untuk umum atau generalisasi yaitu penulis meneliti data-data yang berhubungan dengan elemenelemen harga pokok produksi yang dianggarkan dan data-data yang diperoleh dibahas dengan melakukan perhitungan biaya produksi yang sesungguhnya.

Metode pengumpulan data yang digunakan dalam penelitian ini adalah

1. Dokumentasi

Dokumentasi yang digunakan dalam penelitian adalah dokumen yang dimiliki seperti data absensi karyawan, komponen gaji, perhitungan lainnya yang terkait dengan topik penelitian. Hasil penelitian observasi dan wawancara akan lebih dapat dipercaya bila didukung oleh adanya suatu dokumen.

2. Wawancara

Melalui wawancara inilah peneliti menggali data, informasi, dan keterangan dari subyek penelitian. Teknik wawancara yang dilakukan adalah wawancara bebas terpimpin, artinya pertanyaan yang dilontarkan tidak terpaku pada pedoman wawancara dan dapat diperdalam maupun dikembangkan sesuai dengan situasi dan kondisi lapangan. Wawancara dilakukan kepada pemilik Usaha Tempe Makmur Yaya Tebeng Kota Bengkulu.

Untuk mengelola data yang telah dikumpulkan, maka metode analisis yang digunakan dalam penelitian ini adalah sebagai berikut :

1. Motode kuantitatif adalah analisis terhadap data dari hasil penelitian dengan menggunakan alat atau metode tertentu. Dalam penelitian ukur analisis yang digunakan adalah full costing dan penetapan harga jual menggunakan metode Full Cost Pricing.

a. Metode Full Costing

Menurut (Slamet dan Sumarli, 2015:18.), mengatakan bahwa: Full costing merupakan metode penentuan harga pokok produksi yang memperhitungkan semua unsur biaya produksi, yang terdiri dari biaya bahan baku, biaya tenaga kerja, dan biaya overhead pabrik, baik variable maupun 
tetap.. Dari pengertian di atas dapat ditarik kesimpulan bahwa unsur harga pokok produk menurut metode ini meliputi:
Biaya bahan baku
Biaya tenaga kerja langsung
Rp. $X x x$
Biaya overhead pabrik
Rp. $X x x$
Harga pokok produksi
Rp. Xxx
Rp. Xxx

b. Penetapan harga jual

Menurut (Slamet dan Sumarli, 2015:49.) metode Full Cost Pricing adalah semua jenis biaya dipakai sebagai dasar untuk menentukan harga jual. Jadi semua biaya untuk membuat produk tersebut dihitung ditambah persentase laba yang diinginkan.

Adapun cara menghitung Full Cost Pricing sebagai berikut :

(Biaya produksi total + margin (persentase laba) yang diinginkan)

Sedangkan untuk menghitung Harga pokok produksi perunit meggunakan rumus :

“HPP Perunit = Jumlah semua biaya $:$ jumlah unit yang diproduksi”

\section{HASIL DAN PEMBAHASAN} berikut :

Rata-rata biaya produksi tempe perbuah dengan metode full costing sebagai

Rata-rata harga pokok produksi 1 buah tempe pada tahun 2019 :

$$
\frac{\text { Rp. } 93.048 .865}{26.166 \text { pcs }}=\text { Rp. } 3.556
$$

Rata-rata harga pokok produksi 1 buah tempe pada tahun 2020 :

$$
\frac{\text { Rp. } 226.053 .011}{63.499 \text { pcs }}=\text { Rp. } 3.559
$$

Rata-rata harga pokok produksi 1 buah tempe pada tahun 2021 :

$$
\frac{\text { Rp. } 153.105 .564}{42.999 \text { pcs }}=\text { Rp. } 3.560
$$

Berdasarkan hitungan diatas dapat diperoleh rata-rata harga pokok produksi untuk satu buah tempe dengan menggunakan metode full costing pada Agustus 2019 adalah sebesar Rp. 3.556, tahun 2020 adalah sebesar Rp.3.559 dan Agustus 2021 adalah sebesar Rp.3.560.

Harga Jual yang ditetapkan oleh Usaha Tempe Makmur Yaya Tebeng untuk satu tempe adalah sebesar Rp.5.000 perbuah. Dalam penetapan harga jual metode yang digunakan adalah full cost pricing menurut Slamet dan Sumarli (2015:18) adalah Harga Jual = total biaya produksi + Margin (persentase laba yang diinginkan). 
Menurut (Slamet dan Sumarli, 2015:49.) besarnya penetapan markup laba adalah berdasarkan tarif kembali investasi sebesar 25\% .jika Usaha Tempe Makmur Yaya Tebeng menginginkan laba sebesar 25\% maka dapat dihitung harga jual yang akan diberikan kepada konsumen sebagai berikut :

$$
\begin{aligned}
\text { Harga jual tahun } 2019 & =\text { Rp. } 3 \cdot 556+25 \% \\
= & \text { Rp. } 3 \cdot 556+889 \\
= & \text { Rp. } 4 \cdot 445 \\
\text { Harga jual tahun } 2020 & =\text { Rp. } 3 \cdot 559+25 \% \\
= & \text { Rp. } 3 \cdot 559+890 \\
& =\text { Rp. } 4.449 \\
\text { Harga jual tahun } 2021 & =\text { Rp. } 3.560+25 \% \\
= & \text { Rp. } 3.560+890 \\
= & \text { Rp. } 4.450
\end{aligned}
$$

Maka berdasarkan perhitungan diatas harga pokok produksi tempe pada usaha tempe makmur yaya perbuah pada 2019 sebesar Rp.4.445, tahun 2020 Rp. 4.449

\begin{tabular}{|c|c|c|c|c|c|}
\hline Keterangan & Tahun & $\begin{array}{l}\text { Harga Pokok } \\
\text { Produksi }\end{array}$ & $\begin{array}{c}\text { Harga } \\
\text { Jual }\end{array}$ & $\begin{array}{l}\text { Laba } \\
\text { Bersih }\end{array}$ & $\begin{array}{c}\text { Rata-Rata } \\
\text { HPP }\end{array}$ \\
\hline \multirow{3}{*}{$\begin{array}{l}\text { Metode } \\
\text { perusahaan }\end{array}$} & 2019 & 3.531 & 5.000 & 1.469 & \multirow{3}{*}{1.495} \\
\hline & 2020 & 3.490 & 5.000 & 1.510 & \\
\hline & 2021 & 3.492 & 5.000 & 1.508 & \\
\hline \multirow{3}{*}{$\begin{array}{l}\text { Metode full } \\
\text { costing }\end{array}$} & 2019 & 3.556 & 5.000 & 1.444 & \multirow{3}{*}{1.441} \\
\hline & 2020 & 3.559 & 5.000 & 1.441 & \\
\hline & 2021 & 3.560 & 5.000 & 1.440 & \\
\hline
\end{tabular}
dan pada tahun 2021 sebesar Rp. 4.450 dibulatkan menjadi Rp.5.000 dan perusahaan telah mendapatkan keuntungan $25 \%$.

Berdasarkan hasil penelitian maka dapat diketahui bahwa terdapat perbedaan jumlah harga pokok untuk memproduksi tempe kemasan plastik harga Rp.5000 pada Usaha Tempe Makmur Yaya Tebeng. Adapun perbedaanya dapat dilihat pada tabel berikut.

Tabel Perbandingan perhitungan Harga pokok produksi menurut Usaha Tempe Makmur Yaya Tebeng dengan metode full costing.

Sumber : data diolah. 2021

Berdasarkan tabel diatas dapat terlihat selisih perhitungan antara perhitungan yang dilakukan oleh Usaha Tempe Makmur Yaya Tebeng dengan perhitungan yang dilakukan penulis dengan metode full costing. Menurut perhitungan usaha tempe makmur yaya harga pokok produksi perbuah pada tahun 2019 adalah sebesar Rp.3.531, pada tahun 2020 sebesar Rp.3.490 dan pada tahun 2021 adalah sebesar Rp.3.492 sedangkan menurut metode full costing besarnya harga pokok produksi pada tahun 2019 adalah sebesar Rp. 3.556, tahun 2020 sebesar Rp.3.559 dan pada tahun 2021 adalah sebesar Rp. 3.560. maka adanya perbedaan perhitungan biaya produksi perbuah menurut perhitungan pabrik dibandingkan perhitungan menurut metode full costing pada tahun 2019 sebesar Rp.71, pada tahun 2020 sebesar Rp.69 dan pada tahun 2021 adalah sebesar Rp.68.

Perbedaan ini dikarenakan adanya distorasi biaya penyusutan yang tidak dianggap lagi karena sudah termasuk dalam modal saat membeli, selain itu masih 
banyak lagi biaya produksi yang tidak dihitung sebagai biaya produksi seperti biaya listrik,air,telepondan biaya sewa ojek. Hal ini menyebabkan kecilnya keuntungan yang di peroleh perusahaan karena penentuan harga pokok produksi yang lebih kecil.

Hal ini dikarenakan perhitungan motode full costing lebih rinci dalam memasukan komponen biaya produksi. Sedangkan perhitungan yang dilakukan perusahaan belum secara menyeluruh memasukan komponen biaya yang seharusnya diperhitungkan dalam menetapkan harga pokok produksi seperti biaya overhead pabrik yang belum semuanya dihitung, sehingga nilai yang dihasilkan lebih rendah dibanding perhitungan harga pokok produksi dengan produksi dengan metode full costing.Untuk perhitungan harga jual dengan metode full costing akan menambah jumlah laba yang dihasilkan, hal ini disebabkan karena full costing akan menambah jumlah laba yang dihasilkan, hal ini disebabkan karena full costing memperhitungan biaya lebih rinci dan jumlahnya lebih tinggi.

Dalam penentuan harga jual terdapat perbedaan antara perhitungan yang dilakukan Usaha Tempe Makmur Yaya Tebeng dengan perhitungan yang dilakukan oleh penulis. Usaha tempe makmur yaya menetapkan harga jual berdasarkan harga pasar sedangkan jika peneliti menggunakan metode full costing. Berdasarkan perhitungan diatas dengan menambah keuntungan $25 \%$. usaha tempe makmur yaya mendapat laba dengan harga jual Rp.5000 pada tahun 2019 sebesar Rp. 1.444 perbuah, tahun 2020 sebesar Rp.1.441 perbuah dan pada tahun 2021 sebesar Rp.1.440 perbuah sehingga didapati rata-rata harga pokok produksinya sebesar $\mathrm{Rp}$. 1.495. Sedangkan jika berdasarkan perhitungan pabrik penetapann harga jual berdasarkan pasar. Laba yang diperoleh pada tahun 2019 sebesar Rp. 1.469 perbuah, pada tahun 2020 sebesar Rp.1.510 perbuah dan pada tahun 2021 sebesar Rp.1.508 perbuah sehingga didapati rata-rata harga pokok produksinya sebesar Rp. 1.441. Meskipun laba yang diperoleh lebih tinggi namun pabrik belum memperhitungkan semua biaya yang harus dikeluarkan. Selain itu adanya kenaikan dan penurunan biaya overhead dan biaya bahan penolong membuat laba yang diperoleh seringkali naik turun tergantung pada besar kecilnya tingkat harga pook produksi dan berapa banyak tempe yang diproduksi.

Dengan adanya penentuan harga jual tempe makmur yaya akan memperoleh keuntungan sesuai dengan yang diharapkan. dengan harga pokok produksi yang tepat.

\section{E. KESIMPULAN DAN SARAN}

1) Kesimpulan

Berdasarkan hasil penelitian dan pembahasan dapat diambil kesimpulan berikut ini:

a. Berdasarkan perhitungan harga pokok produksi dengan metode full costing laba yang dihasilkan Usaha Tempe Makmur Yaya Tebeng untuk tempe kemasan plastik harga Rp. 5000 perbuah dengan penetapan harga jual sebesar 25\% dari harga pokok produksi, maka laba yang diperoleh pada tahun 2019 Rp.1.444, pada tahun 2020 sebesar Rp.1.441 perbuah dan pada tahun 2021 sebesar Rp.1.440 perbuah.

b. Berdasarkan perhitungan harga pokok produksi yang dilakukan oleh Usaha Tempe Makmur Yaya Tebeng laba yang dihasilkan untuk tempe kemasan plastik hargaRp. 5000 perbuah dengan penetapan harga jual sebesar $25 \%$ 
adalah pada tahun 2019 sebesar Rp. 1.469 perbuah, pada tahun 2020 sebesar Rp.1.510 perbuah dan pada tahun 2021 sebesar Rp.1.508 perbuah.

c. Diharapkan kepada Usaha Tempe Makmur Yaya Tebeng untuk dapat menerapkan perhitungan harga pokok poduksi berdasarkan metodefull costing dengan tujuan perusahaan dapat menjual tempe dengan mendapatkan keuntungan yang sesuai yang inginkan.

2) Saran

Dari analisis data dan kesimpulan yang diperoleh dalam penelitian, maka penulis dapat memberikan saran kepada Usaha Tempe Makmur Yaya Tebeng yaitu Usaha Tempe Makmur Yaya Tebeng harus melakukan perhitungan lebih terperinci lagi terkait dengan perhitungan biaya overhead pabrik karena pada perhitungan saat ini ternyata Usaha Tempe Makmur Yaya Tebeng belum menyediakan data yang akurat yang berkaitan dengan perhitungan biaya yang harus diperhitungkan dalam menghitung biaya overhead pabrik. Diharapkan kepada Usaha Tempe Makmur Yaya Tebeng untuk dapat menerapkan perhitungan harga pokok poduksi berdasarkan metode full costing dengan tujuan perusahaan dapat menjual tempe dengan mendapatkan keuntungan yang sesuai yang inginkan

\section{DAFTAR PUSTAKA}

Achmad, Slamet dan Sumarli. (2015). Pengaruh Perkiraan Biaya Produksi dan Laba yang Diinginkan Terhadap Harga Jual Pada Industri Kecil Genteng Pres, Jurnal Ekonomi dan Manajemen, Dinamika, Vol. 11, 2, 2002.

Al. Haryono Jusup. (2014). Akuntansi Biaya.Jakarta : Salemba Empat

Bustami, Bastian dan Nurlela. (2013). Akuntansi Biaya. Jakarta: Mitra Wacana Media.

Fahmi, Irham. (2012). Analisis Laporan Keuangan. Bandung : Alfabeta.

Firmansyah, iman. (2015). Akuntansi Biaya Gampang. Bandung: Dunia Cerdas

Heizer, Jay and Render Barry, (2013), Manajemen Operasi :Manajemen Keberlangsungan dan Rantai Pasokan, edisi 11, Salemba Empat, Jakarta.

Hasibuan, Malayu S.P. (2013). Manajemen Sumber Daya Manusia. Cetakan Ketujuh Belas. Jakarta: PT. Bumi Aksara.

Mulyadi. (2015). Akuntansi Biaya, Edisi 5. Yogyakarta :Sekolah Tingg illmu Manajemen YKPN.

Mulyadi. (2014) .Akuntansi Biaya. Edisi-5. Yogyakarta: Universitas Gajah Mada.

Marzeli (2016). Analisis Harga Pokok Produksi Dalam Penentuan Harga Jual Kerupuk Pada Baruna Kerupuk Bengkulu. Skripsi : Universitas Dehasen Bengkulu 
Mewah. (2017). Analisis Harga Pokok Produksi Dalam Penetapan Harga Jual Pada Usaha Rupa Interior Bengkulu. Skripsi : Universitas Dehasen Bengkulu

Novianto Rinto, Sulisti Aprianti, dan Kurniawan. (2020). Profit Planning Analysis On Business Tahu Tempe Baim Manna South Bengkulu District. Skripsi : Universitas Dehasen Bengkulu

Nuraida, Nida. (2013). Tinjauan Atas Perhitungan Harga Pokok Produksi dengan Menggunakan Metode Job Order Costing pada CV Dhira Citra Collection Bandung. repository. widyatama.ac.id. Diakses tanggal 21 Maret 2015.

Siregar, Baldric, Suripto, Bambang, dkk, (2013), “Akuntansi Biaya”, Edisi kedua, Bab 2,7,9-11, Salemba Empat, Jakarta

Salman, Kautsar Riza. (2016). Akuntansi Biaya. Edisi 2. Jakarta: Indeks.

Supriyono. (2013). Akuntansi Biaya dan Penentuan Harga Pokok. Edisi Kedua. Yogyakarta: BPEF.

R.A, Supriyono. (2014). Akuntansi Biaya 1- Pengumpulan Biaya dan Penentuan Harga Pokok. Edisi Kedua. Buku 1. Yogyakarta : BPFE.

Rotinsulu, Paula C. A, Saerang David P. E, dan Dhullo Affandi, (2013). Analisis Pengendalian Biaya Produksi (Studi Kasus Pada PT. Tropica Cocoprima), Jurnal Riset Akuntansi Dan Going Concern Feb Unsrat. ISSN. 1907-9737, Vol. 8 , No. 3

Y. Yuli. (2015). Analisis Harga pokok Produksi Sebagai Dasar Penetapan Harga Jual pada Devisi Fresh Depertemen Bakery PT. Hypermart Kota Bengkulu. Skripsi: Universitas Dehasen . 